\title{
ENCAPSULATION OF PLANT AND ANIMAL OILS USED IN DAIRY INDUSTRY: A REVIEW
}

\author{
Georgi KOSTOV*1, Vesela SHOPSKA*, Rositsa DENKOVA**, Mihaela \\ IVANOVA***, Tatyana BALABANOVA***, Radka VLASEVA*** \\ * Department "Technology of wine and brewing", University of Food \\ Technologies, 4002, 26 Maritza boulevard, Plovdiv, Bulgaria \\ ** Department "Biochemistry and molecular biology", UFT, Plovdiv, \\ Bulgaria \\ *** Department "Technology of milk and dairy products", UFT, Plovdiv, \\ Bulgaria
}

\begin{abstract}
The development of new food products enriched with biologically active components is a topical issue for modern food science and practice. Many of these substances are unstable when being incorporated into the food matrix, which demands a study on the possibilities to stabilize them before use. Encapsulation of biologically active substances is a method which provides stability of the substance in the food product. The principles for implementing encapsulation of biologically active substances, especially natural oils, the matrices and the encapsulation methods are discussed in the present review. Data on the impact of key process parameters of encapsulation, the biological value of oils and the opportunities for application of the encapsulated systems in different groups of dairy products are presented.
\end{abstract}

Keywords: oil encapsulation, methods for encapsulation, dairy industry

\section{INTRODUCTION}

Encapsulation is defined as the process of incorporation of a substance in the matrix of another substance, followed by the preparation of particles having a size of several micrometers to several millimeters. The substance which is subjected to encapsulation forms the core of the capsule and is called active substance. The substance, which ensures the immobilization is called a

\footnotetext{
${ }^{1}$ Corresponding author. Mailing address: Department "Technology of wine and brewing", University of Food Technologies, 4002, 26 Maritza boulevard, Plovdiv, Bulgaria. E-Mail: george kostov2@abv.bg
} 
matrix or a carrier. The basic requirement for both substances is that they are authorized by the regulatory bodies for use in the food industry. The carrier should also provide a stable barrier between the biologically active substances and the food product (Rathore et al., 2013; Zuidam and Shimoni, 2010).

Depending on the chosen method of encapsulation, two types of capsules - a reservoir and a matrix type, are obtained (Figure 1). The reservoir type provides a barrier (membrane) between the medium and the biologically active substance. Poly- or multi-core capsules are capsules with several separate reservoir chambers. In the matrix type capsules the encapsulated material is dispersed in the carrier material. The products obtained during the development of coated capsules may also be classified following the system used in the classification of the matrix formulations. Products of different shapes and sizes ranging from nanometers to a few millimeters are obtained as a result of the process (Rathore et al., 2013; Zuidam and Shimoni, 2010).

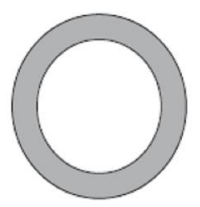

a) reservoir type

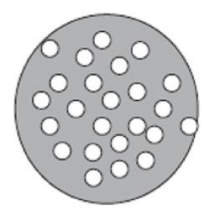

b) matrix type

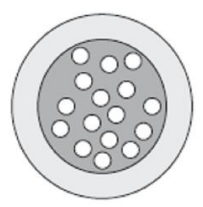

c) matrix type with a membrane

Figure 1. Types of capsules (Zuidam and Shimoni, 2010)

The application of encapsulation in food industry, particularly in the dairy industry, has the following advantages: standard storing of the active agent (oil); immobility of the active substance during food production; improved stability and reduced losses of biologically active substances during the manufacture of the product; reduced oxidation in the immobilization of plant and animal oils; improved product safety; development of visual effects in the product; improvement of the characteristics of the immobilized agent particle size, structure, solubility, color, etc; masking of certain undesirable flavors and aromas arising from the direct use of oils in food; controlled release into food and /or human body. The process is also characterized by some disadvantages (Rathore et al., 2013; Zuidam and Shimoni, 2010): additional costs for process equipment; difficulties in securing the stability of the capsules.

\section{MATERIALS FOR ENCAPSULATION OF BIOLOGICALLY ACTIVE COMPONENTS, PLANT AND ANIMAL OILS}

The main part of the materials currently used for microencapsulation in the food industry are biomolecules - carbohydrates (polysaccharides and polymers), proteins, lipids and biopolymers from various microbial sources 
(Table 1). In some cases inorganic carrier materials can be used, but their use is limited by the requirements of the food legislation (Rathore et al., 2013; Zuidam and Shimoni, 2010).

Table 1. Materials for encapsulation of biologically active components with applications in food industry (Wandray et. al., 2010)

\begin{tabular}{|c|c|c|c|}
\hline Origin & Carbohydrates & Proteins & Lipids \\
\hline Plant & $\begin{array}{r}\text { Starch and its derivatives } \\
\text { Cellulose and its } \\
\text { derivatives } \\
\text { Arabic gum } \\
\text { Karaya gum } \\
\text { Mesquite gum } \\
\text { Galactomannans }\end{array}$ & $\begin{array}{r}\text { Gluten } \\
\text { (maize) } \\
\text { Isolates / } \\
\text { pea, soy }\end{array}$ & $\begin{array}{r}\text { Fatty acids / alcohols } \\
\text { Glycerides } \\
\text { Waxes } \\
\text { Phospholipids }\end{array}$ \\
\hline Algae & $\begin{array}{r}\text { Carrageenan } \\
\text { Alginate } \\
\end{array}$ & & \\
\hline Microbial/animal & $\begin{array}{r}\text { Xanthan } \\
\text { Gellan } \\
\text { Dextran } \\
\text { Chitosan }\end{array}$ & $\begin{array}{l}\text { Casein } \\
\text { Whey } \\
\text { protein } \\
\text { Gelatin }\end{array}$ & $\begin{array}{r}\text { Fatty acids / alcohols } \\
\text { Glycerides } \\
\text { Waxes } \\
\text { Phospholipids }\end{array}$ \\
\hline
\end{tabular}

Regardless of their origin carbohydrates and their derivatives have significant application in the process of encapsulation. Some of the major carriers, applied in food industry, will be discussed in the present review .

\section{A. Starch and its derivatives.}

Starch is a natural homopolymer (chemical formula $\left.\left(\mathrm{C}_{6} \mathrm{H}_{10} \mathrm{O}_{5}\right)_{\mathrm{n}}\right)$, consisting of identical, but architecturally different polysaccharide molecules - linear amylose (20-30\%) and branched amylopectin (70-80\%). The nature and characteristics of starch are determined by the ratio of amylose and amylopectin and their structure in its molecule (Murphy 2000; Parker and Ring 2001). Starch is a white powder, insoluble in cold water, ethanol and most solvents. It is possible to be granulated. Starch is very often modified in order to obtain the desired characteristics for the process of encapsulation. The modification leads to changes in the structure of the hydrogen bonds and improves the industrial application of starch (Elias 1992; Chaplin 2007; Wurzburg 1995, 2006).

Dextrins and cyclodextrins, which are starch derivatives, are the products of degradation of amylose, amylopectin and glycogen under the action of weak acids or in the presence of enzymes. They are also used for encapsulation of 
biologically active substances (Wurzburg 2006; Reineccius et al. 2005; Blanchard and Katz, 2006).

Other products of the derivization of starch applied in encapsulation are polydextrose, maltodextrose, etc. (Elias 1992).

Modified starches and maltodextrins are used as coating agents and fillers in the process of encapsulation in various systems (Shahidi and Regg 1991).

\section{B. Extracts of algae origin - alginate and carrageenan.}

Alginic acid and its salts are probably the most widely used natural polymers for the preparation of microcapsules. They are extracted from brown seaweed and because of its compatibility and simple gellettion they are widely used in the encapsulation of biologically active substances. Structurally, alginic acid is a polymer composed of two sugars - D-mannuronic (M) and L-guluronic acid (G). The M:G ratio, as well as their distribution in the alginate determines the gellation, chemical, mechanical and diffusional properties of the resulting gel, as well as the distribution of its charges (Melvik and Dornish, 2004; Strand et al., 2000). Usually alginates do not possess regularly repeating units (Strand et al., 2000). This block structure determines the elastic properties of alginate gels. The inherent non-plasticity of the alginate molecule depends on the block structure of the alginate and it increases in accordance with the line MG $<$ MM $<$ GG (Melvik and Dornish, 2004). The gelling of the alginate molecule is carried out in the presence of divalent cations. Not all divalent ions lead to the gelling of the alginate. The stability of the complexes is determined by the type of the gelling agents (Kostov, 2015). The process of gelation is described in details in the work of Melvik and Dornish, 2004, and it depends on the concentration of the gel and the type of the gelling agent. Alginates are used for encapsulation of different groups of biologically active substances. They form polyelectrolyte complexes, either alone or in a combination with other materials (Poncelet et al., 2001; Kostov, 2015).

Carrageenan is a polysaccharide extracted from seaweed, which is composed of $\beta$-D-galactose-4-sulfate and 3,6-anhydro- $\alpha$-D-galactose (Leenen, 2001), and the bond between the two components in the molecule determines the type of gel - $i-, \kappa-$ or $\lambda$-carrageenan. The polymer is strongly anionic, allowing the formation of polyelectrolyte complexes with positively charged gels. The carrageenan refers to the so-called thermogels as it dissolves in hot water. Carrageenan gel is formed under mild conditions (by preparing a suspension in cold water), with additional reinforcement of some ions $\left(\mathrm{K}^{+}, \mathrm{Ca}^{2+}, \mathrm{NH}_{4}^{+}\right)$ (Imeson, 2009; Tampion and Tampion, 1987). The most often used type of carrageenan in practice is k-carrageenan, since it forms stable gels with reproducible characteristics. Thus it is used for the encapsulation of different 
groups of biologically active substances, forming polyelectrolyte complexes, either alone or in a combination with other materials (Kostov, 2015).

\section{Materials of microbial and animal origin.}

The group of materials of microbial and animal origin, used for encapsulation of biologically active substances, includes xanthan, gellan, dextran and chitosan. Due to its specific features chitosan has more practical applications (Wandray et. al., 2010).

Chitosan is a copolymer of N-acetyl-D-glucosamine and D-glucosamine (Rinaudo, 2006; Stolarzewicz et al., 2011). The presence of amino groups makes it one of the few cationic polyelectrolytes in nature. Chitosan's excellent gelling properties are due to its solubility in an acidic environment and its ability to react with the anionic polyelectrolytes (Dutta et al., 2002).

Chitosan has a number of properties such as biocompatibility, biodegradability, non-toxicity, physiological inertness, affinity to proteins. It is mainly used in the methods of entapment in gel by ion-formation or by chemical crosslinking with chemical agents (Fujimoto et al., 2006; Hellander et al., 2001; Liu et al., 2004; Liouni et al., 2008; Riddle and Mooney, 2004).

\section{Materials of plant origin.}

This group includes cellulose, its derivatives and certain plant gums (Wandray et. al., 2010).

Cellulose is a natural polymer composed of $\beta$-D-glucose residues linked by $\beta$ (1-4) glycoside bonds. The molecule is arranged so that it forms a rigid structure. Cellulose is insoluble in water and most typical solvents and unlike starch it has more solid crystal structure (Chaplin, 2007). Cellulose is obtained from all plant species, but it can also be synthesized by some acetic acid bacteria and most algae (Wandray et. al., 2010). Typically, cellulose is used as a filler or a carrier for the immobilization of oils after derivatisation. The wood pulp is treated with various chemicals which react with the hydroxyl groups of the cellulose molecule, leading to its derivatization. As a result of that, derivatives like methyl cellulose (MC), hydroxyethyl cellulose (HPMC), hydroxypropyl cellulose and carboxymethyl cellulose are formed. The physicochemical parameters of the cellulose change depending on the degree of derivatization (Chaplin, 2007; Kästner et al. 1997; Butler and Klug 1980; Greminger and Krumel 1980; Wandray et. al., 2010).

Other matrices from this group are wood gum that are complex macromolecular substances. Some of them have mixed structure as they contain oligomers and polymers with different chemical structure. Arabic gum, guar gum and locust bean gum are among the gums with practical application. Gums can be gelled under certain conditions (low temperature; 
changing the $\mathrm{pH}$ ) are therefore are extremely suitable for the encapsulation of biologically active substances including oils (Orozco-Villafuerte et al. 2005; Wandray et. al., 2010).

Another key material for immobilization of plant origin is pectin. It is used in the preparation of microcapsules by gelling the formed solution. Its properties are well known and details on them can be found in literature (May 2000; Lopez da Silva and Rao 2006; Voragen et al. 1995; Wandray et. al., 2010).

\section{BIOLOGICAL CHARACTERIZATION OF PLANT AND ANIMAL OILS AND FATS USED IN DAIRY INDUSTRY}

There are a number of studies on the possibilities for modulating the fatty acid profile and vitamin content of the milk by changing the feeding of the milk-producing animals (Focant et al., 1998; Grumer, 1991; Petit et al., 2002). Another possibility for adjusting the fatty acid profile of the milk fat is its partial replacement with plant oils rich of omega fatty acids (LobatoCalleros et al., 2001; Vial et al., 2006a; 2006b) or fish oil (Huber et al., 2009; Jacobsen, 2008; Jacobsen et al., 2008; Let et al., 2005; Let and Jacobsen, 2006; Nielsen et al., 2007).

Technology development towards replacing milk fat with plant oils rich in omega fatty acids is a current trend in food science in recent years (Bourre, 2007; Buss, 2006; Carantino, 2008; DSM Nutritional products, 2009; Foley and Mellentin, 2006; France-Kelly, 2007; Health ingredient in dairy products, 2010; Ihm et al., 2006; Jopling, 2009; Kolanowski and Weissbrodt, 2007; Lee, 2004; McIntosh et al., 2006; Whelan and Rust, 2007).

Plant oils are a source of essential polyunsaturated fatty acids classified into subgroups such as omega-6 (linoleic and arachidonic) and omega-3 fatty acids ( $\alpha$-linolenic acid, eicosapentaenoic and docosahexaenoic) (Belitz et al., 2009; Hunter, 1989). The human body provides its needs from arachidonic fatty acid through linoleic acid. It is well known that $\alpha$-linolenic acid is a substrate for the synthesis of eicosapentaenoic and docosahexaenoic acid; while linoleic and $\alpha$-linolenic acid are not synthesized by animal cells (Belitz et al., 2009), which identifies them as essential fatty acids.

The proportion of saturated fatty acids in milk fat (about 70\%) is higher than that of plant oils. Maize, sunflower, soybean and other plant oils are characterized by an increased content of unsaturated fatty acids. The proportion of monounsaturated fatty acids is the highest in rapeseed oil $(64 \%$ of the unsaturated fatty acids) and olive oil (75\% of the unsaturated fatty acids), whereas in milk fat they represent $25 \%$ of the fatty acids (Zambiazi et al., 2007). Polyunsaturated omega- 6 and omega- 3 acids are in the largest quantities in sunflower, corn, and soybean oil; linoleic acid is 54 to $65 \%$ of 
the total amount. The content of linolenic acid in sunflower oil is 0.3 to $2.6 \%$, in corn oil it is less than $1 \%$, in soy bean oil - 7-8\%. Linolenic acid is found in lower quantities in olive oil $-0.6 \%$. The content of linoleic acid is within the range of 3,5 - 21\% (Gunstone, 2004). Cotton and peanut oil are characterized by a low content of omega- 3 fatty acids - below 0.3 and $0.1 \%$. Sesame oil contains about $42 \%$ omega- 6 and $0.3 \%$ omega- 3 fatty acids and rice oil contains about $32 \%$ omega- 6 and $0.6 \%$ omega- 3 fatty acids. Rapeseed oil is characterized by relatively high levels of $\alpha$-linolenic acid - 8 to $9 \%$ of the total acid content (Bernard and Carlier, 1992). A very good source of $\alpha$ linolenic acid are also flaxseed and walnut oil, but they are extremely susceptible to oxidation due to their low content of tocopherols and the increased content of unsaturated fatty acids (Gunstone, 2002).

Plant oils also provide to the human body other biologically active substances such as oil-soluble vitamins, tocopherols, phytosterols, lecithin, pigments and other unsaponifiable components in small quantities (Gunstone, 2004).

Tocopherols are defined as effective natural antioxidants, precursors of vitamin $\mathrm{E}$ in several isomeric forms $-\alpha, \beta, \gamma$ and $\delta$. Their content in plant oils is probably related to the amount of unsaturated fatty acids (Gunstone, 2002). It is known that phytosterols - $\beta$-sitosterol, campesterol and stigmasterol are found in plant oils in amounts from $0.5 \%$ to $1.5 \%$. They are characterized by important physiological characteristics - they reduce the absorption of cholesterol and increase the secretion of bile (Gunstone, 2004).

\section{METHODS FOR ENCAPSULATION OF OILS}

A number of methods for encapsulation of biologically active substances are well known and described in literature and practice. Many of these processes start with the preparation of droplets of the active substance (in the form of gas, liquid or powder); then these droplets are covered by the carrier material in a gaseous or liquid medium by physico-chemical processes. In other cases the active substance and the carrier are mixed to form the gel phase and the solid particles are formed by physical, chemical or combined transformations. Part of the encapsulation methods with applications in food industry are summarized in Table 2 (Zuidam and Shimoni, 2010).

Spray drying is the oldest encapsulation process - encapsulation is achieved by dispersing or emulsifying the active ingredient in an aqueous solution of the carrier material. Then the mixture is dispersed in the chamber of the oven (Table 2). The surface of the resulting particles is the carrier material, while water is being evaporated. Spraying is carried out by means of nozzles or disks rotating at a high rate in the counter flow of hot air. The particle size is determined by the air flow rate, its temperature, the amount of atomization of 
the mixture and others (Barbosa-Canovas et al. 2005; Gharsallaoui et al. 2007; Zuidam and Shimoni, 2010).

Covering in a fluidized bed is a technique that uses powdered particles that are coated in the course of a batch or continuous process. The particles are fluidized by air at a suitable temperature and are covered by sprayed through nozzles support material, Over time, each particle is progressively being coated. Materials whose viscosity allows pumping and atomization are used as coating substances. In this case the active substance are the powdered particles which would be coated (Dewettinck and Huyghebaert 1999; Guignon et al. 2002; Zuidam and Shimoni, 2010). Cellulose and starch derivatives, dextrins, proteins, gums and the like are used for coatings in the case of coating in a fluidized bed. The process is controlled by a number of factors like air flow, flow of the coating agent, water content, humidity and air temperature in the chamber (Dewettinck and Huyghebaert 1999; Guignon et al. 2002; Zuidam and Shimoni, 2010).

The specific property of lipids to harden at low temperatures is in the basis of the developed technology of spray freezing. The active agent, subjected to immobilization, can be soluble in lipids, either being in the form of a solid or as an aqueous emulsion (Kjaergaard 2001; Gouin 2004; Zuidam and Shimoni, 2010).

Carbohydrates may be mixed with the active substance, when they are melted at temperatures above $100{ }^{\circ} \mathrm{C}$, and then they can be passed through matrices (extrusion process). At the end of the process they form glassy structures with a low degree of mobility of the active substance. In most cases the process of glazing of the carrier is conducted at temperatures of $30{ }^{\circ} \mathrm{C}$ and $70{ }^{\circ} \mathrm{C}$ (Zuidam and Shimoni, 2010). In this case two similar technical process for encapsulation - vertical and horizontal extrusion - are used (Table 2). The two processes are similar, the difference being in the location in the pressure screw and the matrix, through which the capsules are formed. The most common carriers are polysaccharides, glucose syrups, starch, which can be melted and form a glassy structure at the end of the process. In some cases, the process of encapsulation is optimized by adding the coating materials (Porzio 2004). As a result of these processes particles larger than $2 \mathrm{~mm}$ are generated. These capsules are often soluble in water, but it depends on the type of the used carriers (Zuidam and Shimoni, 2010). 
Table 2. Basic methods for forming of encapsulated formulations of biologically active substances (Zuidam and Shimoni, 2010)

\begin{tabular}{|c|c|c|c|c|c|}
\hline Method & Basic steps & $\begin{array}{l}\text { Type of the } \\
\text { capsule }\end{array}$ & $\begin{array}{c}\text { Specific } \\
\text { loading, \% }\end{array}$ & $\begin{array}{l}\text { Particle } \\
\text { size, } \mu \mathrm{m}\end{array}$ & Scheme \\
\hline 1 & 2 & 3 & 4 & 5 & 6 \\
\hline Spray-drying & $\begin{array}{l}\text { 1. Dispersing or dissolving the } \\
\text { active substance in an aqueous } \\
\text { solution; } \\
\text { 2. Spraying; } \\
\text { 3. Drying. }\end{array}$ & Matrix & $5-50$ & $10-400$ & pemulsion \\
\hline $\begin{array}{l}\text { Coating in a } \\
\text { fluidized bed }\end{array}$ & $\begin{array}{l}\text { 1. Fluidization of the active } \\
\text { powder; } \\
\text { 2. Spray-coating; } \\
\text { 3. Dehydration or cooling. }\end{array}$ & Reservoir & $5-50$ & $5-5000$ & 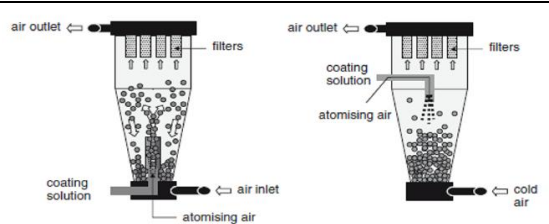 \\
\hline $\begin{array}{l}\text { Spray-freezing } \\
\text { / Spray-cooling }\end{array}$ & $\begin{array}{l}\text { 1. Dispersing or dissolving the } \\
\text { active component in a hot lipid } \\
\text { solution; } \\
\text { 2. Spraying; } \\
\text { 3. Cooling. }\end{array}$ & Matrix & $10-20$ & $20-200$ & \\
\hline Hot injection & $\begin{array}{l}\text { 1. Melting of the coverage; } \\
\text { 2. Dispersing or dissolving the } \\
\text { active component in the coating; } \\
\text { 3. Extrusion through a filter; } \\
\text { 4. Cooling or dehydration. }\end{array}$ & Matrix & $5-20$ & $20-2000$ & \\
\hline
\end{tabular}




\begin{tabular}{|c|c|c|c|c|c|}
\hline 1 & 2 & 3 & 4 & 5 & 6 \\
\hline Hot extrusion & $\begin{array}{l}\text { 1. Melting of the coverage; } \\
\text { 2. Dispersing or dissolving the active } \\
\text { component in the coating; } \\
\text { 3. Extrusion into a twin screw } \\
\text { extruder; } \\
\text { 4. Cooling or dehydration. }\end{array}$ & Matrix & $5-40$ & $300-5000$ & $\mathbf{7}$, water \\
\hline Emulsification & $\begin{array}{l}\text { 1. Dissolving and emulsifying the } \\
\text { component in the aqueous or oil } \\
\text { phase; } \\
\text { 2. Homogenization. }\end{array}$ & Matrix & $1-100$ & $0,2-5000$ & \\
\hline $\begin{array}{l}\text { Encapsulation } \\
\text { by } \\
\text { emulsification } \\
\text { and dispersion }\end{array}$ & $\begin{array}{l}\text { 1. Preparation of the emulsion; } \\
\text { 2. Mixing with polymer solution with } \\
\text { an opposite charge; } \\
\text { 3. Flushing; } \\
\text { 4. Repeating of steps } 2 \text { and } 3 \text {. }\end{array}$ & Reservoir & $1-90$ & $0,2-5000$ & \\
\hline $\begin{array}{l}\text { Encapsulation } \\
\text { by dropping } \\
\text { and / or } \\
\text { emulsification }\end{array}$ & $\begin{array}{l}\text { 1. Dissolving the active component in } \\
\text { the polymer solution / emulsification } \\
\text { in an oil phase; } \\
\text { 2. Dropping in a gelling bath / } \\
\text { Adding a gelling solution while } \\
\text { stirring; } \\
\text { 3. Ion polymer coating. }\end{array}$ & Matrix & $20-50$ & $10-5000$ & 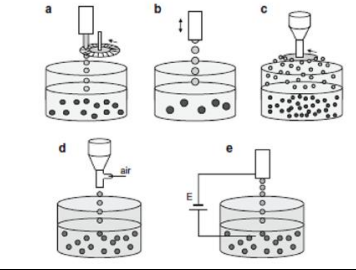 \\
\hline Coextrusion & $\begin{array}{l}\text { 1. Dissolving the active ingredient in } \\
\text { an oil phase; } \\
\text { 2. Preparing a solution of the coating } \\
\text { agent; } \\
\text { 3. Spotting through concentric nozzle } \\
\text { and formation of capsules. }\end{array}$ & Reservoir & $70-90$ & $150-800$ & $\begin{array}{l}0 \\
0\end{array}$ \\
\hline
\end{tabular}


The processes of emulsification, encapsulation by emulsification and encapsulation by gelling the carrier are the most often used processes in practice. These processes are largely connected as they follow one another with a different modidfication (Zuidam and Shimoni, 2010). The simplest way is to emulsify the active substance in an oil phase, forming a stable emulsion which is incorporated in the product. In this case matrix-type capsules are formed. The process depends on a number of factors like the surface tension of the fluid, the temperature and the type of the homogenizer (McClements 2005; Zuidam and Shimoni, 2010).

In other cases, the emulsified component can be put into a solution of the gelling agent, wherein some of the substances of the emulsion will react with the gelling agent so that matrix or reservoir type capsules can be formed. The process parameters depend both on the emulsification and the type of the gelling agent (Zuidam and Shimoni, 2010).

Microencapsulation is a process which is carried out using a variety of techniques. They enable the preparation of capsules of different shapes and sizes, designed for different types of production (Strand et al., 2004). The choice of a method for encapsulation and the corresponding equipment depend on the nature of the core and membrane, the environmental conditions and the application of the capsules. Thus the mechanical stability, the conditions of diffusion of the substances through the membrane and the core, the temperature and $\mathrm{pH}$ of the environment, etc. are important for the implementation of the microcapsules in any industry (Strand et al., 2004; Kostov, 2015).

Microencapsulation as a method of immobilisation is based on the use of water-soluble polymers. They provide mild conditions for the procedures for the formation of the core (for the immobilization procedure), lead to the preparation of a core with good permeability for the products of the metabolism and to some extent they protect the cells against the harmful influences of the external environment. Simultaneously, the formed membrane protects cells from leaking into the fermentation system, and if the conditions for the membrane's preparation are suitable, very stable mechanically capsules can be obtained. For the preparation of microcapsules with a defined shape, dimensions and characteristics different techniques like ion polymer coating, phase inversion and surface precipitation are used. Among these methods the easiest process to implement is ion polymer coating. In this case, the resulting capsules are placed in a solution of another 
polymer forming stable bonds as a result of which a membrane is formed above the capsule (Strand et al., 2004; Kostov, 2015).

\section{APPLICATION OF ENCAPSULATED SYSTEMS IN DAIRY INDUSTRY}

The contemporary trends in human nutrition require from food ingredients to ensure the proper functioning of the body and to contain specific ingredients with beneficial physiological effects on human health. Dairy products are characterized by high nutritional and biological value and are a suitable base for the incorporation of various biologically active substances with potential health benefits. The biologically active substances are unstable in some technological processes (heat treatment, the acidity of the medium containing $\mathrm{NaCl}$, etc.) which reduce their absorption in the human body. When added to food, some of the substances affect negatively the organoleptic characteristics of the food product.

The development of healthy foods by the addition of biologically active substances requires certain technological approaches. Thus the demand for opportunities for encapsulation of biologically active substances with proven health activities is scientifically justified. Encapsulation is a suitable method for improving the bioavailability of biologically active substances in the human body and is accomplished using various natural matrices. The resulting microcapsules may be enriched with various biologically active substances and viable bacterial cells (Lu-E et al., 2013).

Various methods of preparing microcapsules, which are successfully used in food industry and in the production of various milk-based foods, have been established.

Data on the use of microcapsules containing probiotic bacteria in dairy products - cheese, yogurt and ice cream can be found in literature. Encapsulation preserves lactic acid bacteria and significantly limits their reduction in their passage through the human gastrointestinal tract (Benech et al., 2002; El-salam \& El-shibiny, 2012; Livney, 2008; Lu-E et al., 2013; Nazzaro et al., 2012; Puupponen-Pimiä et al., 2002).

A number of authors explore the opportunities to develop healthy dairy products enriched with microcapsules containing polyunsaturated fatty acids, $\alpha$-tocopherol, polyphenols, carotenoids and antioxidants (Burgain et al., 2011; Nazzaro et al., 2012). 
A technology for microencapsulation of omega-3 fatty acid, ensuring conservation of the biologically active substances during processing technology has been developed (Augustin et al., 2005). The resulting microcapsules are being implemented in the production of cheese (Bermudes-Aguirre and Barbosa-Canovas, 2011).

Another research team (Santos et al., 2011) applied essential oils incorporated in microcapsules in fresh cheese, cheese spreads and butter, which increased the biological value and the antioxidant activity of the products.

Microcapsules containing lipase are used in cheese production, aiming at activating the process of lipolysis during maturation (Champagne and Fustier, 2007; Hélène et al., 2013; Stratulata et al., 2014).

Data on increasing the biological value of foods for infants and children through the incorporation of nanocapsules containing casein, providing proteins and minerals to the body of the adolescent has been published (Doherty et al., 2012; Forrest et al., 2005; Semo et al., 2007; Singh, 2006).

\section{ACKNOWLEGMENTS}

This work is supported through project №7/15-H of fund "Science” at University of Food Technologies.

\section{REFERENCES}

1. Augustin, M. A., Sanguansri, L. \& Kead, R. (2005). GI tract delivery systems. WO2005/0489981A1.

2. Barbosa-Canovas, G.V., Ortega-Rivas, E., Juliano, P., H. Yan, H. (2005). Food Powders. Physical properties, processing, and functionality. Kluwer Academic/Plenum Publishers, New York

3. Belitz, H., Grosch, W., Schieberle, P. (2009), Food Chemistry, SpringerVerlag, Berlin Heidelberg.

4. Benech R.-O., Kheadr, E. E., Lacroix, C., Fliss, I. (2002). Antibacterial activities of nisin encapsulated in liposomes or produced in situ by mixed culture during cheddar cheese ripening. Appl. Environ. Microbiolvol., 68, 11, 5607-5619.

5. Bermúdez-Aguirre, D., Barbosa-Cánovas, G. (2011). Quality of selected cheeses fortified with vegetable and animal sources of omega-3. Food Science and Technology, 44, 1577 - 1584. 
6. Bernard, A., Carlier, H. (1992). Aspects nutritionnels des constituants des aliments. Influence des technologies, Les Cahiers de l'ENSBANA, TecDoc Lavoisier, France, 100 - 200.

7. Blanchard, P.H., Katz, F. R. (2006). Starch hydrolysates. In: Food polysaccharides and their applications. Stephen, A.M., G. O. Phillips, P. A. Williams (Eds.), 2nd edn. Taylor \& Francis, Boca Raton, FL, 119145.

8. Bourre, J., (2007). Dietary omega-3 fatty acids for women. Biomedical Pharmacology, 61, 2, 105 - 112.

9. Burgain, J., Gaiani, C., Linder, M., Scher, J. (2011). Encapsulation of probiotic living cells: From laboratory scale to industrial applications. Journal of Food Engineering, 104, 4, 467-483.

10. Buss, D., (2006). Dairy tries for full omega-3 line-up, New Nutrition Business, 11, 7, 26.

11. Butler, R.W., Klug, E. D. (1980). Hydroxypropylcellulose. In: Handbook of water soluble gums and resins. Davidson, R.L. (Ed.). McGraw-Hill, New York, 13-1-13-6.

12. Carantino, S. (2008). Heath related dairy products becoming more and more convincing. Revue Laitiere Francaise, 676, 28-30.

13. Champagne, C. P. \& Fustier, P. (2007). Microencapsulation for delivery of probiotics and other ingredients in functional dairy products. Book Functional dairy products, 2, 404-426.

14. Chaplin, M.F. (2007). Water structure and Science. http://www.lsbu.ac.uk/water/.

15. Dewettinck, K., Huyghebaert, A. (1999). Fluidized bed coating in food technology. Trends Food Sci Tech, 10, 163-168.

16. Doherty, S. B., Auty, M. A., Stantos, C., Ross., R.P., Gitzgerald., G. F., Brodkorb, A., (2012). Survival of entrapped Lactobacillus rhamnosus GG in whey protein micro-beads during simulated ex vivo gastrointestinal transit. International dairy journal, 22, 31-43.

17. DSM Nutritional Products, (2009), Omega-3 LC-PUFA a new era in omega-3 dairy fortification begins, Nutraceuticals Now, (Autumn), 40 41.

18. Dutta, P.K., Ravikumar, M.N.V., Dutta, J. (2002). Chitin and chitosan for versatile applications, J Macromol Sci, C42:307-54.

19. Elias, H.-G. (1992). Makromolekule. Band 2, Technologie. Huthig \& Wepf Verlag, Basel, Heidelberg, New York. 
20. El-Salam, M. A., El-shibiny, S. (2012). Formation and potential uses of milk proteins as nano delivery vehicles for nutraceuticals: a review. International Journal of dairy tehnology, 65, 13-21.

21. Filomena, N., Orlando, P., Fratianni, F., Coppola, R. (2012). Microencapsulation in food science and biotechnology. Current Opinion in Biotechnology, 23, 2 182-188.

22. Focant, M., Mignolet, E., Marique, M., Clabots, F., Breyne,T., Dalemans, D., Larondelle, Y. (1998). The effect of vitamin E supplementation of cow diets containing rapeseed and linseed on the prevention of milk fat oxidation, Journal of Dairy Science, 81, 4, 1095 1101.

23. Foley, M, Mellentin, J. (2006). Omega-3 brings new benefits. Kids Nutrition Report., 2, 6, 5-6.

24. Forrest, S. A., Yada, R. Y., Rousseau, D. (2005). Interaction of vitamin D3 with bovin with $\beta$-lactoglobulin and $\beta$-casein. Journal of agricultural and food chemistry, 53, 8003-8009.

25. France-Kelly, C. (2007). DHA omega-3: the future of food, Food Marketing and Technology, 20, 6, 14-15.

26. Gharsallaoui, A., Roudaut, G., Chambin, O., Voilley, A., Saurel, R. (2007). Applications of spray-drying in microencapsulation of food ingredients: an overview. Food Res Intern, 40, 1107-1121.

27. Girouxa, J. H., Constantineaua, S., Fustiera, P. Claude, P., Champagnea, D. St., Lacroix, M., Brittena, M. (2013). Cheese fortification using water-in-oil-in-water double emulsions as carrier for water soluble nutrients, International Dairy Journal, 29, 2 107-114.

28. Gouin, S. (2004). Microencapsulation: industrial appraisal of existing technologies and trends. Trends Food Sci Tech, 15, 330-347.

29. Greminger G.K. Jr, Krumel, K. L. (1980). Alkyl and hydroxyalkylalkylcellulose. In: Handbook of water soluble gums and resins. Davidson, R.L. (Ed.), McGraw-Hill, New York, 3-1-3-25.

30. Grumer, R. (1991). Effect of feed on the composition of milk fat. Journal of Dairy Science, 74, 9, 3244 - 3257.

31. Guignon, B., Duquenoy, A., Dumoulin, E. D. (2002). Fluid bed encapsulation of particles: principles and practice. Drying Technol 20, 2 , 419-447.

32. Gunstone, F., (2002). Vegetable oils in food technology: composition, properties and uses. Blackwell, Oxford, UK, 98-128. 
33. Gunstone, F., (2004), The Chemistry of Oils and Fats. Wiley-Blackwell, 140-210.

34. Health ingredients in dairy products. Where next?, (2010), Deutsche Milchwirtschaft, v. 61, № 13, 442 - 443.

35. Huber, G., Rupasinghe, H., Shahidi, F. (2009). Inhibition of oxidation of omega-3 polyunsaturated fatty acids and fish oil by quercetin glycosides, Food Chemistry, 117, 290-295.

36. Hunter, J. (1989). Scientists discuss dietary fatty acids. Journal of the American Oil Chemists' Society, 66, 1251 - 1256.

37. Ihm, K., Kurtzke, K., Halbach, T., Mueller, A., Ritter, S., Muschiolik, G., Scherze, I., Jahreis, G., Schubert, R. (2006). Process for manufacture of a nutritionally improved mixed dairy product, such as yoghurt or cheese, and the mixed milk product produced, Patent Number: DE 10 2004052061 A1.

38. Imeson, A. (2009). Carrageenan, In: Handbook of hydrocolloids, ed. by Phillips, G.O., Williams, P.A. (Eds.). Woodhead Publishing Limited, 87102

39. Jacobsen, C. (2008). Omega-3 in food emulsions: overview and case studies. Agrofood Industry Hitech, 19, 5, 9-12.

40. Jacobsen, C., Let, M., Nielsena, N., Meyer, A. (2008). Antioxidant strategies for preventing oxidative flavour deterioration of foods enriched with n-3 polyunsaturated lipids: a comparative evaluation. Trends in Food Science \& Technology, 19, 76 - 93.

41. Jopling, D. (2009). Omega-3 in foods: the story so far, Food Science and Technology, 23, 3, 40 - 41.

42. Kastner, U., Hoffmann, H., Donges, R., Hilbig J. (1997). Structure and solution properties of sodium carboxymethyl cellulose. Colloids Surf A: Physicochem Eng Asp, 123, 307-328.

43. Kjaergaard, O.G. (2001). Multiple-core encapsulation: Prilling. In: Microencapsulation of Food Ingredients. By Vilstrup, P. (Ed.), Leatherhead Publishing, Surrey, 197-214.

44. Kolanowski, W., Weissbrodt, J. (2007), Sensory quality of dairy products fortified with fish oil, International Dairy Journal, 17, 10, 1248-1253.

45. Kostov, G. (2015), Intensification of fermentation processes with immobilized biocatalysts, DSc thesis, Plovdiv, p.307.

46. Lee, D. (2004). Dairy products: milking the functional way, Asia Pacific Food Industry, 16, 5, 46-48. 
47. Leenen, E.J.T.M. (2001). Description of support material, In: Immobilized cells, Wijfels, R.H. (Ed.). Springer, 6-14

48. Let, M., Jacobsen, C. (2006). Preventing oxidation in milk enriched with omega-3 fatty acids, Lipid Technology, 18, 4, 77-81.

49. Let, M., Jacobsen, C., Meyer, A. (2005). Sensory stability and oxidation of fish oil enriched milk is affected by milk storage temperature and oil quality, International Dairy Journal, 15, 173-182.

50. Livney, Y. D. (2008). Complexes and conjugates of biopolymers for delivery of bioactive ingredients via food. In: Delivery and controlled release of bioactives in foods and nutraceuticals. Garty, N. (Ed.), Woodhead, Cambridge, UK, 234-250.

51. Lobato-Calleros, C., Robles-Martinez, J., Caballero-Perez, J., AguirreMandujano, E., Vernon-Carter, E. (2001). Fat replacers in low-fat Mexican Manchego cheese, Journal of Texture Studies, 32, 1-14.

52. Lopez da Silva, J.A., Rao, M. A. (2006). Pectins: Structure, functionality, and uses. In: Food polysaccharides and their applications, Stephen, A.M., Phillips, G. O., Williams, P. A. (Eds.), 2nd edn. Taylor \& Francis, Boca Raton, FL, 353-411.

53. Lu-E. S., Zhen-Hua, L., Dan-Ting, L., Min, X., Huai-Yu, C., Zhi-Liang, Z., Zhen-Xing, T. (2013). Encapsulation of probiotic Lactobacillus bulgaricus in alginate - milk microspheres and evaluation of the survival in imulated gastrointestinal conditions. Journal of food engineering, 117, 99-104.

54. May, C.D. (2000). Pectins. In: Handbook of hydrocolloids. Phillips, G.O., Williams., P. A. (Eds.). Woodhead Publishing Limited, Cambridge, England, 169-188.

55. McClements, D.J. (2005). Food Emulsions. Principles, practices and techniques. CRC Press, Boca Raton.

56. McIntosh, G., Roupas, P., Royle, P. (2006). Cheese, omega-3 fatty acids, conjugated-linoleic acid and human health. Australian Journal of Dairy Technology, 61, 2, 142-146.

57. Melvik, J.E., Dornish, M. (2004). Alginate as a carrier for cell immobilization. In: Fundamentals of cell immobilization biotechnology, Focus on Biotechnology, Nedovic, V. Willaert, R. (Eds.). Kluwer Academic Publishers, 33-51.

58. Murphy, P. (2000). Starch. In: Handbook of hydrocolloids. Phillips, G.O., Williams., P. A. (Eds.). Woodhead Publishing Limited, Cambridge, England, pp 41-65. 
59. Nielsen, N., Debnath, D., Jacobsen, C. (2007). Oxidative stability of fish oil enriched drinking yoghurt. International Dairy Journal, 17, 1478 1485.

60. Orozco-Villafuerte, J., Buendia-Gonzalez, J., Cruz-Sosa, F., VernonCarter, E. J. (2005). Increased mesquite gum formation in nodal explants cultures after treatment with a microbial biomass preparation. Plant Physiol Biochem, 43, 802-807.

61. Parker, R., Ring, S. G. (2001). Aspects of the physical chemistry of starch. J Cereal Sci., 34, 1-17.

62. Petit, H., Dewhurst, R., Scollan, N., Proulx, J., Khalid, M., Haresign, W., Twagiramungu, H., Mann, G. (2002). Milk production and composition, ovarian function and prostaglandin secretion of dairy cows fed omega-3 fats, Journal of Dairy Science, 85, 4, 889-899.

63. Poncelet, D., Dulieu, C., Jacquot, M. (2001). Description of immobilisation procedures, In: Immobilized cells, Wijfels, R.H. (Ed.), Springer, 15-30

64. Porzio, M. (2004). Flavor encapsulation: a convergence of science and art. Food Technology, 58, 7, 40-47.

65. Puupponen-Pimia, R., Aura, A. M., Oksman-Caldentey, K. M., Myllarinen, P., Saarela, M. Mattila - Sandholm, T., Poutanen, K. (2002). Development of functional ingradients for gut health. Trends in food and science technology, 13, 3-11.

66. Rathore, S., Desai, P. M., Liew, C. V., Chan, L. W., Wan Sia Heng, P. (2013). Microencapsulation of microbial cells. Journal of Food Engineering, 116, 369-381.

67. Reineccius, T.A., Reineccius, G. A., Peppard, T. L. (2005). The effect of solvent interactions on alpha-, beta-, and gamma-cyclodextrin flavor molecular inclusion complexes. J. Agric. Food Chem., 53, 388-392.

68. Rinaudo, M. (2006). Chitin and chitosan: Properties and applications, Prog. Polym. Sci., 31, 603-632.

69. Santos, S., Ressuriecao, S., Marques, R., Pintado, M. (2011). Encapsulation of natural flavors for use in dairy products, 11 th International congress on engineering and food process engineering in a changing world, 3, 2067-2069.

70. Semo, E., Kesselman, E., Danino, D., Livney, Y. D. (2007). Casein micelle as a natural nano-capsular vehicle for nutraceuticals. Food hydrocoloids, 21, 936-942. 
71. Shahidi, F.R., Regg, R. B. (1991). Encapsulation of the pre-formed cooked cured-meat pigment. J Food Sci, 56, 1500.

72. Singh, H., (2006). The milk fat globule membrane-a biophysical system for food applications. Current opinion in colloid \& interface science, 11, 154-163.

73. Stolarzewicz, I., Biaiecka-Florjacczyk, E., Majewska, E., Krzyczkowska J. (2011). Immobilization of yeast on polymeric supports, Chem. Biochem. Eng. Q., 25, 1, 135-144.

74. Strand, B.L, Skjak-Braek, G., Gaserod, O. (2004). Microcapsule formulation and formation, In: Fundamentals of cell immobilization biotechnology, Focus on Biotechnology, Nedovic, V., Willaert, R. (Eds.). Kluwer Academic Publishers, 2004, 165-184.

75. Strand, B.L, Morch, Y.A., Skjak-Braek, G. (2000). Alginate as immobilization matrix for cells, Minerva Biotec, 12, 223-233.

76. Stratulata, I., Brittenb, M., Salmieria, S., Fustierb, P., St-Gelaisb, D., Champagne, C., Lacroix, M. (2014). Enrichment of cheese with bioactive lipophilic compounds. Journal of Functional Foods, 6, 48-59.

77. Tampion, J., Tampion, M.D. (1987). Immobilized cells: Principles and Application, Cambridge University press, 77-108

78. Vial, C., Thakur, R., Pérez Quintóns, A., Djelveh, G., Picgirard, L. (2006b). Continuous manufacturing of a light-textured foamed fresh cheese by dispersion of a gas phase. II. Influence of formation, Journal of Food Engineering, 77, 14 - 26.

79. Vial, C., Thakur, R., Pérez Quintóns, A., Djelveh, G., Picgirard, L. (2006a), Continuous manufacturing of a light texture foamed fresh cheese by dispersion of a gas phase. I. Influence of process parameters, Journal of Food Engineering, 77, 1 - 13.

80. Voragen, A.G.J., Pilnik, W., Thibault, J.-F., Axelos, M. A. V., Renard., C. M. (1995). Pectins. In: Food Polysaccharides and their applications. Stephen, A. M. (Ed.). Marcel Dekker, Inc, New York, 287-339.

81. Wandray, C., Batrowiak, A., Harding, S. (2010). Materials for Encapsulation. In: Encapsulation Technologies for Food Active Ingredients and Food Processing, Zuidam, N.J., V.A. Nedovic (Eds.). Springer: Dordrecht, The Netherlands; 31-100.

82. Whelan, J., Rust, C. (2007). Innovative dietary sources of n-3 fatty acids, Annual Review of Nutrition, 26, 75-103. 
83. Wurzburg, O.B. (1995). Modified starches. In: Food Polysaccharides and their applications. ed. By Stephen, A.M. (Ed.). Marcel Dekker, Inc, New York, 67-97.

84. Wurzburg, O.B. (2006). Modified starches. In: Food polysaccharides and their applications, ed. by Stephen, A.M., Phillips, G. O., Williams, P. A. (Eds.). 2nd edn. Taylor \& Francis, Boca Raton, FL, 87-118.

85. Zambiazi, R., Przybylski, R., Zambiazi, M., Mendonca, C. (2007). Fatty acid composition of vegetable oils and fats, Boletim do Centro de Pesquisa de Processamento de Alimentos, 25, 1, 111 - 120.

86. Zuidam, N.J., Shimoni, E. (2010). Overview of microencapsulates for use in food products or processes and methods to make them. In: Encapsulation Technologies for Food Active Ingredients and Food Processing, ed. by Zuidam, N.J., Nedovic V.A. (Eds.), Springer: Dordrecht, The Netherlands. 3-30. 